УДК 66.088

\title{
Еранская Татьяна Юрьевна
}

Институт геологии и природопользования ДВО РАН

г. Благовещенск, Россия

E-mail: taerta@mail.ru

Eranskaya Tatiana Yurievna

Institute of Geology and Nature Management, FEB RAS

Blagoveshchensk, Russia

E-mail: taerta@mail.ru

\section{ОПРЕДЕЛЕНИЕ ОПТИМАЛЬНОГО ТЕМПЕРАТУРНОГО ИНТЕРВАЛА ДЛЯ ПРЕДВАРИТЕЛЬНОГО ОБЖИГА КАОЛИНА}

\section{DETERMINATION OF THE OPTIMAL TEMPERATURE RANGE FOR PRE-FIRING KAOLIN}

Аннотация. Исследовано влияние предварительного обжига каолиновых концентратов на выход гидроксида алюминия при азотнокислотном выщелачивании кавитационным методом. Интервал обжига $700-750^{\circ}$ С является оптимальным для максимальной вскрываемости каолинового концентрата.

Abstract. The effect of pre-firing of kaolin concentrates on the yield of aluminum hydroxide during nitric acid leaching by cavitation method is studied. The firing interval of 700-750 ${ }^{\circ} \mathrm{C}$ is optimal for maximum opening of kaolin concentrate.

Ключевые слова: обжиг, температурный интервал, каолиновый концентрат, азотнокислотное разложение.

Key words: kaolin concentrate nitric acid solution, decomposition of kaolin, cavitation, ultrasonic apparatus, the temperature of the process.

DOI: 10/22250/jasu.14

В условиях, когда месторождения бокситов истощаются, необходимо искать другие источники для производства глинозема. Такими источниками могут быть широко распространенные глинистые каолинсодержащие породы - каолины, нефелины и др. На территории Амурской области находится Чалганское месторождение каолинсодержащих песков, общие балансовые запасы которого составляют 65,48 млн. тонн [1]. Годовой выпуск обогащенного мокрым способом каолина на комбинате «Опытный» (в период его работы) составлял 50 тыс. тонн [2]. Этот каолиновый концентрат может использоваться для производства бумаги, санитарно-технических, фарфоровых и керамических изделий и в других целях. В табл. 1 приведен химический состав каолиновой породы и продуктов ее первичной переработки в пересчете на безводное вещество.

Каолиновые концентраты с таким и более низким содержанием оксида алюминия могут использоваться при производстве глинозема. Например, глины Ангренского месторождения содержат 23,50 масс. \% $\mathrm{Al}_{2} \mathrm{O}_{3}$ [3], а кыштымские каолины на Урале - до 42,00 масс. \%.

Каолиновые концентраты состоят из минерала каолинита, оксида кремния и в небольших количествах - сопутствующих минералов на основе оксидов из табл. 1.

Источником глинозема в каолиновом концентрате является каолинит. Его химическая формула $\mathrm{Al}_{4}\left[\mathrm{Si}_{4} \mathrm{O}_{10}\right](\mathrm{OH})_{8}$, или $\mathrm{Al}_{2} \mathrm{O}_{3} \cdot 2 \mathrm{SiO}_{2} \cdot 2 \mathrm{H}_{2} \mathrm{O}$ с соотношением $\mathrm{Al}_{2} \mathrm{O}_{3}: \mathrm{SiO}_{2}: \mathrm{H} 2 \mathrm{O}=39,5 \%: 46,5 \%: 14,0 \%$ [4]. 
Таблииа 1

Химический состав каолиновой породы (КП) и концентратов

(КМ-1, КН-73) Чалганского месторождения, масс. \% [2]

\begin{tabular}{|c|c|c|c|}
\hline Оксиды & КП & КН-73 & KM-1 \\
\hline $\mathrm{SiO}_{2}$ & 81,67 & 58,01 & 53,93 \\
\hline $\mathrm{Al}_{2} \mathrm{O}_{3}$ & 15,58 & 39,09 & 42,61 \\
\hline $\mathrm{Fe}_{2} \mathrm{O}_{3}$ & 0,49 & 0,82 & 1,11 \\
\hline $\mathrm{TiO}_{2}$ & 0,4 & 0,54 & 0,69 \\
\hline $\mathrm{Na}_{2} \mathrm{O}$ & 0,14 & 0,16 & 0,13 \\
\hline $\mathrm{K}_{2} \mathrm{O}$ & 1,73 & 1,38 & 1,53 \\
\hline Сумма & 100 & 100 & 100 \\
\hline
\end{tabular}

Каолинит имеет двухслойную структуру. Его химическую формулу часто записывают как $2\left(\mathrm{Al}_{4}\left[\mathrm{Si}_{4} \mathrm{O}_{10}\right](\mathrm{OH})_{8}\right)$. Связь между слоями компенсирована находящимися напротив друг друга гидроксильными ионами и атомами кислорода. Поэтому у кристаллической решетки каолинита практически отсутствует способность к внутрикристаллическому разбуханию. Вследствие чего катионы реагентов не могут проникать в межпакетное пространство. В результате каолинит имеет низкую химическую активность. Его емкость обмена составляет $3 \cdot 10^{-3} \ldots .5 \cdot 10^{-3}$ моль/100 г [4].

Чтобы повысить реакционную активность каолинита, необходимо устранить водородно-кислородные связи между слоями путем удаления структурированной воды из решетки каолинита нагреванием до определенных температур. Удаление воды сопровождается переходом каолинита в аморфную структуру метакаолинита, который имеет высокую химическую активность к различным химическим реагентам. Например, при температуре выше $700^{\circ} \mathrm{C}$ (табл. 2) вода в структуре каолина практически отсутствует, а каолинит имеет аморфную структуру (рис. 1). Пики на дифрактограмме принадлежат свободному $\mathrm{SiO}_{2}$, входящему в каолиновый концентрат.

Таблииа 2

Состав исходного и обожженного каолина, \%

\begin{tabular}{|c|c|c|c|c|c|c|c|c|c|c|c|c|}
\hline Оксиды & $\mathrm{SiO}_{2}$ & $\mathrm{Al}_{2} \mathrm{O}_{3}$ & $\mathrm{TiO}_{2}$ & $\mathrm{Fe}_{2} \mathrm{O}_{3}$ & $\mathrm{MnO}$ & $\mathrm{CaO}$ & $\mathrm{MgO}$ & $\mathrm{Na}_{2} \mathrm{O}$ & $\mathrm{K}_{2} \mathrm{O}$ & $\mathrm{P}_{2} \mathrm{O}_{5}$ & Lоi() & Сумма \\
\hline Исходный каолин & 50,44 & 32,83 & 0,41 & 1,46 & 0,01 & 0,36 & 0,24 & 0,20 & 1,45 & 0,02 & 12,42 & 99,84 \\
\hline \multicolumn{10}{|c|}{ Обожженный каолин при температуре обжига, ${ }^{\circ} \mathrm{C}$} \\
\hline 600 & 56,42 & 37,20 & 0,46 & 1,65 & 0,01 & 0,41 & 0,20 & 0,18 & 1,63 & 0,02 & 1,60 & 99,78 \\
\hline 700 & 55,75 & 38,46 & 0,48 & 1,69 & 0,01 & 0,42 & 0,26 & 0,19 & 1,66 & 0,03 & 0,79 & 99,74 \\
\hline 800 & 57,15 & 37,35 & 0,46 & 1,66 & 0,01 & 0,41 & 0,20 & 0,19 & 1,62 & 0,02 & 0,70 & 99,77 \\
\hline
\end{tabular}

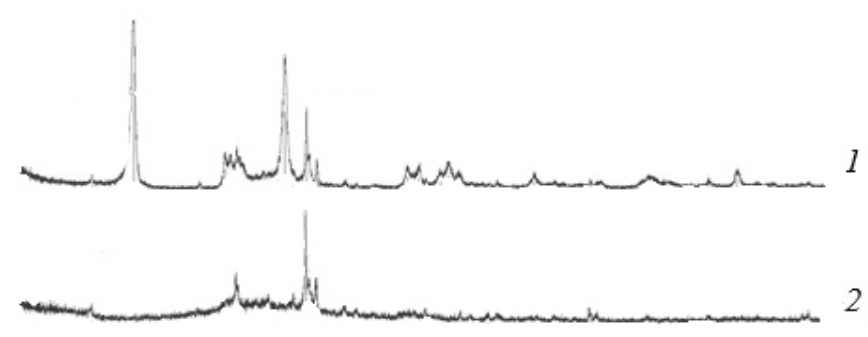

Puc. 1. Дифрактограммы образцов:

1 - исходный каолиновый концентрат;

2 - концентрат после обжига при $700^{\circ} \mathrm{C}$.

При любой кислотной технологии получения глинозема из каолинового концентрата предварительный обжиг является обязательной операцией. Все исследователи заключают, что максимальной реакционной способностью обладают каолины, обожженные при температурах $650-750^{\circ} \mathrm{C}$. Время данной операции обычно составляет от одного до пяти часов. В соответствии с нашей технологией каолин выдерживали при постоянной температуре в течение 1, 3 и 6 часов, а затем охлаждали до температуры окружающей среды вместе с печью. В табл. 2 приведены данные о химическом составе образцов, полученных при температуре обжига в течение трех часов. При температурах обжига ниже $700^{\circ} \mathrm{C}$ в структуре каолинита остается часть структурированной воды, которая препятствует полному разложению, а при более высоких - приобретает последовательно структуру $\gamma-\mathrm{Al}_{2} \mathrm{O}_{3}, \beta-\mathrm{Al}_{2} \mathrm{O}_{3}, \alpha-\mathrm{Al}_{2} \mathrm{O}_{3}$, что также препятствует полному разложению. 
Эксперименты по выщелачиванию (разложению) обожженного каолинового концентрата азотной кислотой проводились по кавитационной технологии. Максимальный результат 83,78\% от расчетного получен для каолина, обожженного при температуре $700^{\circ} \mathrm{C}$ (рис. 2).

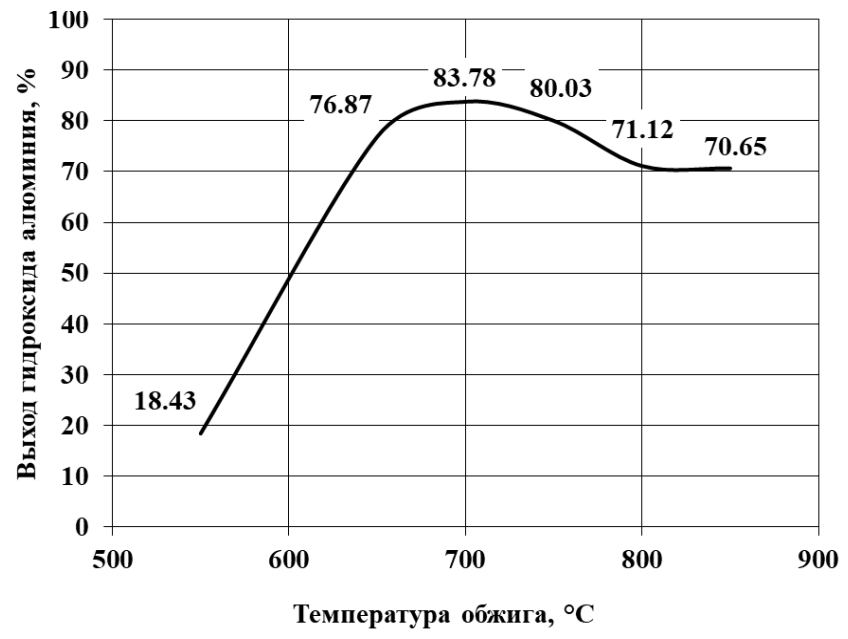

Puc. 2. Выход готового продукта от температуры предварительного обжига.

Данные эксперименты с каолиновыми концентратами проводились с целью определения оптимальных параметров разрабатываемой кавитационной технологии по азотнокислотному выщелачиванию обожженных каолинов.

1. Нежинец, В.Н. Каолины // Геология СССР. - М.: Недра, 1976. - Т. 19. - С. 141-144.

2. Римкевич, В.С. Экспериментальные исследования магматической несмесимости в силикатно-солевых системах в связи с разработкой методов извлечения алюминия из горных пород. - Благовещенск, 2001. $-211 \mathrm{c}$.

3. Кенжаев, М.Э., Исламова, М.Ш., Мирзакулов, Х.Ч. Исследование влияния процесса прокалки на извлечение окиси алюминия из ангренских каолинов // Universum: Технические науки: электрон. научн. журнал. 2017. - № 4(37). - URL: http://7universum.com/ru/tech/archive/item/4678

4. Солодкий, Н.Ф., Шамриков, А.С., Погребенков, В.М. Минерально-сырьевая база Урала для керамической, огнеупорной и стекольной промышленности. Справочное пособие / под ред. проф. Г.Н. Масленниковой. Томск: Изд-во ТПУ. 2009. - 332 с.

УДК 331.45

Иваныкина Татьяна Викторовна

Амурский государственный университет

г. Благовещенск, Россия

E-mail: tat-ivanykina@yandex.ru

Ivanykina Tatiana Viktorovna

Amur State University

Blagoveshchensk, Russia

E-mail: tat-ivanykina@yandex.ru

Чупраков Андрей Евгеньевич

Амурский государственный университет

г. Благовещенск, Россия

E-mail: andrey.chuprakov.99@mail.ru

Chuprakov Andrei Evgenevich

Amur State University

Blagoveshchensk, Russia

E-mail: andrey.chuprakov.99@mail.ru 